\title{
On-street parking search: A UK local authority perspective
}

\author{
Sarah Brooke \\ Loughborough University \\ S.L.Brooke@lboro.ac.uk \\ Mohammed Quddus \\ Loughborough University \\ M.A.Quddus@lboro.ac.uk
}

\author{
Stephen Ison \\ Loughborough University \\ S.G.Ison@lboro.ac.uk
}

\begin{abstract}
Vehicles searching for parking create an environmental and economic impact. Despite negative externalities for individual drivers and society as a whole, there is a dearth of research in the area of parking search from the perspective of local government authorities. The aim of this paper is to ascertain the perceptions of local authority policymakers in relation to parking search. City and county council officers within the East Midlands area of the United Kingdom indicate a lack of recorded evidence regarding the volume of vehicles searching for parking, which creates an issue both in terms of establishing the existence of parking search and in quantifying the level of the problem. However, council officers express consensus in the view that on-street parking search is more likely to occur within peripheral urban areas away from the core city center, as such areas may be lacking in parking facilities of the type that are typically provided in central urban areas, such as large off-street surface car parks or multi-story parking facilities. Local council officers perceive that parking search is more prevalent in larger market towns that attract a large number of visitors for shopping and personal business purposes but that are not able to provide sufficient parking supply to meet peak period demand.
\end{abstract}

\section{Article history:}

Received: November 19, 2013

Received in revised form:

September 12, 2015

Accepted: September 16, 2015

Available online: June 28, 2016

\section{$1 \quad$ Introduction}

Searching for parking occurs when an individual reaches his or her destination, intends to park, and proceeds to drive around an area searching for a parking space that fulfills specific requirements for that particular journey. On-street parking search creates a problem for individuals and society due to negative externalities arising from additional vehicle miles traveled on the wider traffic network; an impact defined as "a random access queue that interferes with traffic flow" (Arnott and Inci 2010). The environmental and economic impact can be quantified in terms of increased network traffic flow and

Copyright 2015 Sarah Brooke, Stephen Ison \& Mohammed Quddus

http://dx.doi.org/10.5198/jtlu.2015.600

ISSN: 1938-7849 | Licensed under the Creative Commons Attribution - Noncommercial License 3.0

The Journal of Transport and Land Use is the official journal of the World Society for Transport and Land Use (WSTLUR) and is published and sponsored by the University of Minnesota Center for Transportation Studies. This paper is also published with sponsorship from WSTLUR and the Institutes of Transportation Studies at the University of California, Davis, and University of California, Berkeley. 
congestion (Arnott and Inci 2006), noise emissions and air pollution (van Ommeren, Wentink, and Rietveld 2012), time delays, for individuals who are searching and for through traffic delayed by the slower vehicle speeds of searching vehicles (Anderson and De Palma 2004), and safety hazards (Axhausen and Polak 1989) caused by vehicles maneuvering into and out of on-street parking spaces. It has been estimated that cars searching for parking constitute 14 percent of traffic density and generate a 50 percent increase in congestion-related time loss (Arnott and Rowse 2009). In a review of 16 studies conducted in 11 US cities, Shoup (2006) estimated on average 30 percent of traffic was searching for parking, with 8.1 minutes average search time. Estimated commuting time increased approximately 20 percent due to parking search time (van Ommeren, Wentink, and Dekkers 2011).

It is apparent from the literature that much of the research investigating parking search has been undertaken from the perspective of individual drivers who are searching for a parking space that fulfills their particular needs. Given the potentially significant impact of parking search in urban areas, which may have far-reaching implications in terms of parking and transport policy, this paper investigates the views of local government officials relating to parking search. It is possible (and indeed likely) that the perspectives of local government officers concerning parking policy may differ substantially from those of motorists, who typically are more concerned with parking decisions as they attempt to find a parking space rather than wider societal impacts. Indeed, research investigating the difference in opinions between professional economists and those of the general public in the United States found systematic differences between the economic beliefs of laypersons and experts (Caplan 2002). However, despite the findings in this study being limited to local authority perceptions of parking search, the council officers interviewed are professional individuals who are focused on parking and transport issues in their daily work life. As outlined in a study by Taylor et al. (2002) in which transit managers were interviewed, the council officers could similarly be considered as having expressed the opinions of informed observers and therefore offering useful insights into perceptions of parking search in urban areas of the United Kingdom.

Much of the parking search research in the United Kingdom dates back to the early 1990s and indicates that parking search is influenced by numerous individual trips and personal and physical characteristics of on-street parking places. Existence of spatial aspects (not all areas within a city experience equivalent levels of parking search) and temporal elements (varying numbers of vehicles search for parking according to the time of day, day of the week, and time of year) are highlighted as influencing parking search decisions. Due to the impact of lengthy parking search times on congestion and economic vitality, policymakers are becoming aware of the need to implement transport demand measures to address this issue, often through pricing mechanisms and examining the interaction between on- and offstreet parking supply. Eliminating parking search, "pure deadweight loss" (Arnott and Inci 2006), can be achieved from an economic perspective by increasing on-street parking charges or allocating more on-street space to parking. Applying a policy of off-street parking price reductions aligned with on-street parking fees discourages parking search behavior (Barter 2012). How parking pricing has affected the likelihood of searching for parking and choice of parking place has been investigated by van Ommeren, Wentink, and Dekkers 2011, which found that individuals were more likely to search for parking when on-street parking was inexpensively priced compared to off-street parking facilities. Parking search could be eliminated by charging on-street parking at market-price (Manville 2014; Shoup 2004) and pricing adjacent on- and off-street parking equally (Shoup 2006). Spatial and temporal elements exist to onand off-street parking search (van Ommeren, Wentink, and Rietveld 2012); search time was found to increase with parking and travel duration, form morning peaks, and occur more frequently in cities experiencing higher numbers of vehicle trips. Individuals experience various constraints on their time; one such constraint is to arrive at a workplace on time, hence parking search is more likely to occur among 
individuals undertaking retail or leisure activities who have fewer time pressures than those individuals engaged in employment or business activities (van Ommeren, Wentink, and Rietveld 2012).

More recently, advances in technology are having an impact on parking search, with search time declining in urban areas that have introduced technological solutions to increase the availability of parking spaces to meet demand. For instance, the SFpark scheme in San Francisco installed embedded sensors in on-street parking spaces to indicate real-time parking occupancy of each space and implemented dynamically variable parking charges according to demand for on-street metered parking spaces (Chatman and Manville 2014; Millard-Ball, Weinberger, and Hampshire 2014; Pierce and Shoup 2013). Internet websites, such as Parkopedia.com, CarPark4You.com, and Confused.com make available to drivers advanced information as to the location of parking places around a desired destination, thereby reducing the need for parking search on arrival. Other dynamic technological advances in the form of mobile phone (smartphone) applications assist motorists in locating and potentially reserving and paying for a vacant parking space remotely by informing drivers as to where vacant spaces are located in real-time and thus reducing the need for parking search (Nawaz, Efstratiou, and Mascolo 2013). New technologies have the potential to have a considerable impact on parking search in areas where they are implemented, yet many policymakers are slow to realize the gains that these could offer in parking policy, either through lack of awareness or from perceived prohibitive costs.

Additional challenges in implementing appropriate policies can be observed between private organizations such as car park owners, whose aim is usually to maximize profits, and local government authorities, who are publicly funded and need to consider how the provision of on- and off-street parking infrastructure integrates with an overarching urban transport strategy within which parking policy forms a subset. Furthermore, implementing strategic decisions in the areas of parking and transport policy will often entail sensitive and controversial decisions and could risk alienating large numbers of individuals for the sake of creating wider societal benefits (Butler 2012). A further tension in parking policy that exists for local authorities is ensuring accessibility of urban areas to preserve local economic activity and vitality, revenue raising from parking charges, and transport demand management (Rye and Koglin 2014), with a typical emphasis on sustainable travel modes. This is of particular importance in destinations experiencing regular high demand for parking spaces, particularly if supply is unable to fulfill this demand, thus leading to high levels of parking search. In such instances, policy measures based on controlling access to available spaces by type of user (for instance, commuters, shoppers, tourists, business users, and residents) through mechanisms such as on-street time and price regulations and permit schemes may be introduced. Given the importance of understanding parking search and its importance in influencing future policy decisions, the aim of this study is to obtain the perceptions of local authority policymakers in relation to parking search in order to establish the level of understanding and awareness of parking search as a potentially significant transport policy issue. Understanding the impact of parking search and how this may be affected by parking standards and design principles (Weinberger 2014) is important for understanding the wider impacts on individuals and society that may arise from future parking policies. To this end, an important research question focuses on the level of parking search that is perceived by policymakers to exist within different cities in the United Kingdom and, more pertinent to this paper, the perceived level of parking search within cities in the East Midlands region of the United Kingdom. Further research questions concern the nature of the spatial and temporal characteristics of parking search. An important outcome of the study is to enable the future development of informed urban parking policy in which an effective and coherent on-street parking strategy (Marshall 2014) can help reduce the occurrence of parking search. The following section outlines the method used. The main findings obtained from the research are then detailed, while the final section discusses the findings, draws some conclusions, and highlights areas for future research. 


\section{Method: Qualitative local authority study}

This research was conducted using a qualitative approach in the form of semi-structured interviews. This method was chosen due to the greater flexibility in questioning offered, in addition to the likelihood of eliciting greater detail about specific parking search issues. Furthermore, the technique provided the opportunity to gain potential insights into parking search and parking policy by allowing interviewees to explore the issues in a semi-structured way (Bryman 2012). Ten interviews were conducted with city and county council transport and parking officers across the East Midlands region of the United Kingdom during October and November 2013 (Table 1).

Table 1: East Midlands' council officers interviewed for the study

\begin{tabular}{|c|l|l|}
\hline ID & \multicolumn{1}{|c|}{ Position } & \multicolumn{1}{|c|}{ Council } \\
\hline 1 & Head of Regulatory Services & Charnwood Borough Council \\
\hline 2 & $\begin{array}{l}\text { Civil Parking Enforcement Manager } \\
\text { Network Management }\end{array}$ & Derbyshire County Council \\
\hline 3 & $\begin{array}{l}\text { Transport Manager } \\
\text { Economy, Transport and Environment Group }\end{array}$ & Derbyshire County Council \\
\hline 4 & $\begin{array}{l}\text { Group Manager } \\
\text { (Transport Strategy and Projects) }\end{array}$ & Leicester City Council \\
\hline 5 & $\begin{array}{l}\text { Group Manager (Transport Planning) } \\
\text { Traffic and Safety Group }\end{array}$ & Leicestershire County Council \\
\hline 6 & $\begin{array}{l}\text { Team Manager (Traffic Management) } \\
\text { Traffic and Safety Group }\end{array}$ & Leicestershire County Council \\
\hline 7 & $\begin{array}{l}\text { Network Manager } \\
\text { Transport and Accessibility Directorate }\end{array}$ & Lincolnshire County Council \\
\hline 8 & $\begin{array}{l}\text { Parking Manager } \\
\text { Transport and Accessibility Directorate }\end{array}$ & Lincolnshire County Council \\
\hline 9 & $\begin{array}{l}\text { Project Support Officer } \\
\text { Transport and Commercial Services }\end{array}$ & $\begin{array}{l}\text { Parking Operations Manager } \\
\text { Parking Services }\end{array}$ \\
\hline
\end{tabular}

It was planned for each interview to be between one and two hours to allow sufficient time for discussion, expanding out from the initial questions posed to the interviewees. The applied sampling technique entailed an initial approach to city and county councils within the four main counties of the East Midlands region of the United Kingdom: Nottinghamshire, Leicestershire, Derbyshire, and Lincolnshire. Having selected the four counties in which to conduct the interview surveys, targeted sampling took place, with individual interviewees being selected according to the number of years experience in a role that had responsibility for making transport and/or parking policy decisions across each local authority area. The interviewees had each held senior transport management roles within a city, county, or borough council of between six and 32 years and had responsibility for implementing parking policy and embedding it within a council's overall transport strategy.

The interviews consisted of 13 pre-prepared open-ended questions that were selected by reference to the literature on parking search and were used as prompts to stimulate discussion. These commenced with broader questions about transport issues, before focusing more specifically on parking issues within transport policy. As this research was particularly concerned with drivers on-street parking search decisions, several of the questions focused on aspects of parking search; for example, is this considered to be 
a significant problem in UK cities, are certain groups of people more likely to undertake parking search, and spatial and temporal patterns in relation to search within each of the cities with councils involved in the interviews. Council officers were additionally asked about their perceptions of anticipated future parking search patterns, based on their years of experience working in parking and transport policy and observation of parking search within each city. Table 2 outlines the structure of the semi-structured questions and the focus of the main topics discussed, as developed from the literature.

Table 2: Interview questions

\begin{tabular}{|c|c|}
\hline 1 & your view, what are the main transport issues affecting cities in the UK? \\
\hline 2 & What do you consider to be the most significant parking issues in UK cities? \\
\hline 3 & $\begin{array}{l}\text { Do you consider parking search to be an issue in UK cities and, if so, how serious an issue would you perceive it to be } \\
\text { in relation to other parking issues? }\end{array}$ \\
\hline 4 & $\begin{array}{l}\text { Do you think there is a problem with parking search in Leicester/ Nottingham/Derby/Lincoln? If so, how would you } \\
\text { perceive the seriousness of the issue in relation to other UK cities? }\end{array}$ \\
\hline 5 & $\begin{array}{l}\text { Are there any specific factors in Leicester/Nottingham/Derby/Lincoln that you think influence the likelihood of park- } \\
\text { ing search occurring? }\end{array}$ \\
\hline 6 & $\begin{array}{l}\text { Are there specific groups of motorist (for example, shoppers, tourists, commuters, leisure users) whom you believe are } \\
\text { more or less likely to search for parking? If yes, what do you perceive to be the reasons for this? }\end{array}$ \\
\hline 7 & In your experience, does the level of parking search vary according to time of day, day of the week, or time of year? \\
\hline 8 & $\begin{array}{l}\text { Are there areas of Leicester/Nottingham/Derby/Lincoln in which parking search is more likely to occur and if so, in } \\
\text { which areas? }\end{array}$ \\
\hline 9 & Do you think parking search has changed over time? If so, in what ways and why? \\
\hline 10 & $\begin{array}{l}\text { If parking search is perceived as a problem in Leicester/ Nottingham/ Derby/ Lincoln, has Leicester/Nottingham/ } \\
\text { Derby/Lincoln City Council implemented any parking management policies in order to address parking search? If } \\
\text { yes, what measures have been introduced and how effective have these been in addressing the issue of parking search } \\
\text { and wider parking and transport issues? Have there been wider benefits arising from the policy implementation and, if } \\
\text { so, what are they? }\end{array}$ \\
\hline 11 & $\begin{array}{l}\text { In addition to policy measures which may have been identified in the previous question, what do you believe are pos- } \\
\text { sible solutions to address the issue of parking search? What might be the challenges of implementing these solutions } \\
\text { (for instance cost or public acceptability) and how might these challenges be overcome? }\end{array}$ \\
\hline 12 & $\begin{array}{l}\text { In your view, what are the likely future developments in parking search? Do you think parking search will become a } \\
\text { greater or lesser issue and what are the reasons for your response? }\end{array}$ \\
\hline 13 & $\begin{array}{l}\text { What do you consider to be the likelihood of Leicester/Nottingham/Derby/ Lincoln City Council adopting policy } \\
\text { measures to address parking search in the future, and how would such measures fit with the current objectives of } \\
\text { Leicester/Nottingham/Derby/Lincoln City Council? }\end{array}$ \\
\hline
\end{tabular}

The qualitative interview data was analyzed by performing the most commonly used research method-thematic content analysis (Neuendorf 2002)—to identify implicit and explicit ideas or themes across the interview surveys conducted with council officers. This inductive approach enabled the complexities of meaning, including similar or differing views of respondents, to be identified, examined, and understood, thus ensuring the interviewees experiences of parking and parking search issues were interpreted accurately and comprehensively (Joffe and Yardley 2004). Themes were coded to provide clarity to the interviews and to answer research questions. Interpretation of interview meanings was helped by including, alongside the codes, supportive evidence from the text, thus offering the advantage of analyzing the frequency of codes (representing themes) together with analysis of their meaning in context. This provided greater transparency to the interpretation of the interviews and also enabled more complex inferences to be reached (Joffe and Yardley 2004). 


\section{$3 \quad$ Findings}

The main themes identified from the thematic content analysis are outlined in Table 3. Common themes emerged from the various interviews, with similar perspectives and opinions being expressed by respondents. To protect respondent anonymity, comments have been identified in the paper as Respondent 1 , Respondent 2 , etc.

Table 3: Themes identified from the interview surveys

\begin{tabular}{|c|c|}
\hline Overarching Theme & Issue \\
\hline \multirow{2}{*}{ Traffic } & Traffic flow \\
\hline & Congestion \\
\hline \multirow{3}{*}{ Parking } & Pricing \\
\hline & Supply/Capacity \\
\hline & Demand (varies) \\
\hline \multirow{2}{*}{ Parking Search } & Uncertainty over level of current search occurring \\
\hline & Concern over potential impact on traffic flow \\
\hline \multirow{3}{*}{ Spatial Patterns } & Between city core and peripheral areas \\
\hline & Between cities and market towns \\
\hline & Within cities (around key destinations) \\
\hline \multirow{3}{*}{ Temporal Patterns } & Time of Day (mornings/evenings) \\
\hline & Day of Week (weekdays/weekends) \\
\hline & Time of Year (holiday periods and Christmas) \\
\hline \multirow{5}{*}{ Trip Purpose } & $\begin{array}{l}\text { Different search patterns/likelihood of search } \\
\text { varies: }\end{array}$ \\
\hline & Commuters \\
\hline & Shoppers \\
\hline & Social and entertainment users \\
\hline & Tourists \\
\hline \multirow{3}{*}{ Parking Search Patterns } & Past - more search \\
\hline & Present - less search (economic recession) \\
\hline & Future - progressively more search \\
\hline Solutions to Parking Search & Technological - cost prohibitive \\
\hline Policy Implications & $\begin{array}{l}\text { Willingness to implement (if evidence of parking } \\
\text { search) }\end{array}$ \\
\hline
\end{tabular}

\section{$4 \quad$ Traffic}

All council officers in the study identified the main traffic issue affecting UK towns and cities as congestion and the resulting effect on the economy through time delays. This was highlighted during an interview with Respondent 5, who stated: "Congestion is most certainly our main issue of concern and I think would be top of the list of traffic concerns for most (UK) cities." Other issues focused on increasing travel demand through continuing growth in car ownership, usage, and reliance on the car as a primary transport mode. The respondents were concerned about the effect of these issues on air quality and emissions, particularly in terms of meeting future European legislative targets for air quality.

\section{$5 \quad$ Parking}

When asked about the most significant parking issues affecting UK cities, the responses focused on how on-street parking impacts traffic flow. The discussion also focused on the challenge in providing a level of parking in these cities to maintain a thriving local business economy. Nottingham City Council 
found it difficult to balance a requirement to earn revenue from on-street parking charges against a policy of maintaining traffic flow and encouraging more sustainable travel options. They explained this dilemma by describing how they needed to charge for parking at higher levels than two of the other cities to increase the revenue obtained from parking and offset reduced central government funding levels. However, alongside this requirement was the need for the council to reduce the number of vehicles traveling into and parking in the city to meet sustainability targets and maintain a smooth traffic flow. It was difficult for them to balance the desire to encourage more vehicles in order to obtain higher revenues from parking while simultaneously being seen as promoting sustainable transport alternatives to private car use. The cost of parking was also raised as an issue in some cities, "...in some areas parking is quite expensive..." (Respondent 7), in particular, the perceived high cost from the point of view of drivers. The negative perception among the general public about robust enforcement of illegal parking was mentioned as being a problem. However, the alternative view was that strict enforcement gave rise to increased turnover, which benefited drivers and local businesses. More specific issues related to a lack of appropriate parking provisions for different trip purposes (such as commuters, shoppers, and leisure users) for which varying parking durations must be supplied.

\section{$6 \quad$ Parking search}

Several of the respondents were unsure as to how much of an issue parking search was both within the United Kingdom as a whole and within specific cities. The general feeling emerged that parking search could well be an issue, but they had not identified or quantified it to show evidence of a serious problem in any of the cities in the study: "(there is) no real hard evidence (of parking search) at the moment" (Respondent 5). Others thought it was an issue but not the most serious transport or parking concern: "There isn't a significant problem...although (parking search) probably does take place" (Respondent 4). However, vehicles searching for parking contribute to congestion, which is considered by most of the respondents as a primary transport problem. The interaction between on- and off-street parking was thought to play an important role in parking search. For instance, one factor that respondents identified as influencing the occurrence of parking search was the signage, quality, and tariffs of off-street car parks, which determined whether individuals wanted to park there or not. Drivers evaluated these elements alongside on-street parking restrictions (duration), how strictly these restrictions were enforced, and the parking charges for on-street spaces. Several council officers described the challenges they faced in providing off-street parking at a competitive price that matched private car park operators. While all of the councils owned off-street car parks in addition to on-street parking, they explained that many private operators were able to offer parking at considerably lower cost than was possible for the publicly owned council authorities, in many instances, by operating on illegally occupied land. This was a legal issue that some of the officers were currently involved in addressing. It was acknowledged by the respondents that, from the point of view of the general public, cheap off-street parking was to be welcomed, and furthermore, in preventing such sites from operating, occurrences of parking search could increase due to fewer available parking spaces. In some areas of the cities studied there was considerably higher demand than in other areas that had fewer attractors (such as in the vicinity of a sports arena); hence parking search was likely to occur in areas of high demand despite overall parking capacity across a city being sufficient to fulfill required demand. While minimum parking standards exist in the United Kingdom for new construction, development in the cities in the study has been established for a considerable number of years prior to parking standards regulation and hence does not provide parking spaces at a level that fulfills demand. This has the effect of increasing parking search in city centers. Respondents additionally identified residential parking zones as an influencing factor as they reduced the on-street parking capacity available to non-residents. A factor unique to one city (Nottingham) is the Workplace Parking Levy 
(WPL), which has resulted in some employers reducing the amount of on-site parking, thus displacing employees out of employer-provided car parks and leading them to search for free-of-charge on-street parking. This has resulted in increased parking search away from the core city center, affecting the outer districts of Nottingham where employees are now choosing to park since employer-provided spaces are not available. The impact of this displacement is that parking places that are now occupied by commuters (employees) has led to a shortage of spaces and hence more parking search for residents and hospital visitors in these areas experiencing higher demand.

\section{$7 \quad$ Spatial patterns}

Respondents initially expressed the reaction that parking search does not appear to create much of a problem, but consideration revealed the extent that vehicles searching for parking could have in creating a more serious issue in defined areas. A distinction was made between core city centers in the East Midlands, where parking search "is less of an issue because of (the presence of) multi-story parking facilities," whereas "for slightly peripheral activities requiring short periods of parking and where off-street car parks are not conveniently located, parking search is more likely to occur" in cities such as Leicester (Respondent 4). Parking search was additionally thought to be a more significant issue when a driver was traveling to a single specific destination and was aware of the existence of on-street parking (particularly if associated with an accompanying shortage of off-street parking provision) around the end destination; the driver was then more likely to search for an on-street parking space. Similarly, officers identified parking search as being more likely to occur where a specific destination existed that attracted a large number of people but which had a shortage of parking, such as retail parks, entertainment or sports venues, tourist attractions, or around key employment sites (particularly those that had reduced workplace parking arising from more restrictive planning regulations), where the available on-street capacity quickly reached saturation. This raised the point that patterns of parking search may change over time as towns and cities develop residential, retail, and business areas; hence current areas which have greater on-street parking demand might in the future shift to other areas within cities.

Furthermore, it was thought that parking search is a greater issue in larger towns in Lincolnshire (for instance Boston, Grantham, Sleaford, and Stamford) and in market towns such as Louth, where "on-street parking is free and the town is quite a compact area with narrow streets and lots of independent boutique shops, (thereby) attracting lots of visitors" (Respondent 8). Similarly, Leicestershire County Council thought that larger towns in the county (for instance Hinckley and Melton Mowbray), which attract a large number of visitors to events such as farmers markets but are lacking infrastructure supply in terms of on- and off-street parking to fulfill periods of particular high parking demand, are more likely to experience increased occurrences of parking search. While Charnwood Borough Council described parking search in the market town of Loughborough as occurring among infrequent visitors (for instance, business people or contractors needing to park outside residential properties), who were unfamiliar with the area.

\section{Temporal patterns}

It was observed that parking search varied according to time of day, day of the week, and time of year, with peak parking times (not always aligned with peak traffic times) affecting the likelihood of parking search, such as in Nottingham during evenings after 6 p.m., when on-street parking charges become cheaper, and after 8 p.m., when on-street tariffs no longer apply, and also at core times (10:30 a.m.-2 p.m.) on weekends when shopping trips become more popular. Similarly, on Sundays in Leicester, no on-street parking charges apply, hence increased parking search occurs, while core times (10:30 a.m.-3 
p.m.) on Saturdays were identified as busy shopping periods when search increased due to high parking demand. Morning periods were identified across all cities as generally having more parking search occurrences for shopping and business purposes, while evenings generated search for entertainment and social purposes. Entertainment venues such as the leisure facility in Leicester, which has a large on-street parking capacity in the surrounding locality, was observed as generating more parking search around evening performances. From mid-November through December, search occurred more frequently among Christmas shoppers visiting the cities. Furthermore, the start of the new university year in October was identified as being particularly busy with an increase in parking search. While in one particular town, market days were identified as giving rise to increased search, particularly on Thursdays when usual visitors came to the town for shopping, business, and commuting purposes were augmented by a large number of market visitors: "market days are very busy... search may occur on these days" (Respondent 1).

\section{Trip purpose}

The interviewees all agreed that trip purpose affected the likelihood of parking search, with commuters being most unlikely to search for parking as they tend to park in the same area (close to their place of work) and arriving early in the morning when there are typically on-street spaces available. Shoppers, tourists, and leisure users were thought to be more likely to search as they usually had more time available (no work start time to meet), a point highlighted by Respondent 10: "Shoppers and leisure users have time to search...tourists are quite likely to search... but possibly not at the main congestion times." One council expressed the opinion that parking search was "an issue at peak periods for shoppers, due to a limited number of on-street parking bays being insufficient to service the retail outlets in the area ... leading to drivers circulating until they find a space" (Respondent 7). This led to increased driver stress through searching and waiting for an available space and, if unable to find a space, to individuals departing and visiting out-of-town areas, with the associated loss of trade to local business. Others observed areas of intense parking demand within each city (typically where there is a destination that attracts a large number of individuals, such as a market, retail area, or sports or entertainment venue) where parking search is more likely. One respondent commented that familiarity with an area would affect likelihood of parking search, with individuals expressing greater familiarity being less likely to need to search as they could time their arrival at a destination when they knew parking would be available. This contrasted with other respondents who thought individuals who were unfamiliar with an area would be less likely to search as they would choose to follow signage that would guide them to an off-street car parking facility. However, drivers who are unfamiliar with an area but who know that plentiful on-street parking exists will search for on-street parking rather than follow guidance signs to off-street car parks: "People who go there (hospital) regularly know where the on-street parking is..." (Respondent 4). It was also noted that drivers who are unfamiliar with an area may initially set out to follow signs to an offstreet car park, but if they pass on-street parking on the way, they may choose to abandon their original plan and park on-street instead. It was thought that parking search might increase in the evenings due to on-street parking charges being considerably reduced or removed altogether in some cities.

\section{Parking search patterns}

There was general agreement among council officers that parking search patterns have changed over time due to rising demand for parking attributed to increasing car ownership and usage, yet no corresponding growth in supply. In some areas there has been a reduction in on-street parking through tighter controls on provision and rising numbers of residential parking zones that due to a reduced number of 
available spaces increased the occurrence of parking search. In contrast to the view of there being rising demand for parking, several council officers also expressed the view that parking search appeared to be less of a problem than five years ago (since before the UK economic recession), with current parking supply able to meet the demand, as observed by Respondent 4: "There is reduced demand for parking in general and on-street parking as part of that (because of the economy)." A sentiment reflected by Respondents 9 and 10, who observed that the effect of pricing and time restrictions on on-street parking places had an impact on the local economy through deterring shoppers and visitors. This led to changes in on-street parking charges and time limits, which have succeeded in reversing this trend, as explained by Respondent 9: “...(the council) has looked again at the pricing (of on-street parking)... has brought people back in again...certainly the evening (visitors) and Sunday shoppers...(the council)...is looking at the wider picture."

All councils interviewed agreed that the most likely future scenario for parking search patterns was for the number of vehicles searching for parking to increase in the next few years as the economy recovers and demand for parking correspondingly increases. Therefore, agreement existed among the council officers that in the future parking search is likely to become a greater issue. This will result from a growing population, rising car ownership and usage, economic growth as the UK economy emerges from recession, and growth in business and residential development arising from a recovering economy, and hence increasing demand for on-street parking but no corresponding increase in availability of supply. This sentiment was outlined by Respondent 1: "...parking search will become, over the next 20 years, a greater issue and more of a problem... as the country develops." However, satellite technology may have the potential to provide information to motorists about the availability of vacant on-street spaces in addition to off-street car parks, which would therefore reduce the need for parking search. Likewise, if changes in city center usage create fewer attractors encouraging people to visit (such as changes in retail or work patterns), there could also be a decline in parking search. Despite both technological advancement and changes in city center usage patterns, the respondents thought that the most likely future scenario would be for parking search to become a more significant issue in urban areas.

\section{Solutions to parking search}

When asked about possible solutions to parking search, a common view expressed was to improve the information provided for drivers, "...provide the correct information...tailored to the right people" (Respondent 2) about potential parking places available for different trip purposes (with varying durations and tariffs) to enable advanced planning before arriving at a city and potentially reducing parking search. Officers suggested that improved integration of on- and off-street parking provisions in terms of pricing structures, time restrictions, and overall capacity to enable both types to operate more effectively alongside one another would reduce parking search. Pricing as a solution to parking search was also discussed, with council officers giving examples of where they had adjusted the parking tariffs for various time-bands and different areas of each city to encourage or discourage parking at certain times of day and within various areas of a city where there was greater (or lesser) parking supply and demand. Other solutions put forward were more technologically advanced, such as parking sensors within parking bays that would inform drivers through smartphone applications of the availability of vacant parking spaces, thus enabling drivers to approach a vacant space and avoid the necessity of prior search. The local authorities believed such technological solutions to be financially prohibitive and would be considered only in the future if parking search were shown to be a serious problem affecting cities. 


\section{Policy implications}

None of the councils had implemented policy measures specifically to address parking search. All respondents instead reported transport policies aimed at facilitating traffic flow, which is of particular importance on major networks into, out of, and within each city, and parking management measures aimed at ensuring parking provision operates effectively alongside transport policy in maintaining an efficient network. If evidence indicated that parking search was a problem that "impacts on the efficiency of the (traffic) network" (Respondent 3), policies would be developed and implemented to directly address parking search. These policies included re-examining pricing strategies across the various city core and peripheral parking areas for both on-street and (local authority owned) off-street car parking facilities, in addition to adjusting the time restrictions for on-street parking. The likelihood of individual city or county councils adopting specific policy measures to address parking search would be dependent on gathering evidence to demonstrate that parking search is a serious problem affecting management of an urban transport network. If this were shown, then officers stated that they would develop policies to address the issue, which would effectively align with the implementation of other sustainable transport objectives. However, other councils suggested that a tension existed between, for instance, encouraging greater public transport use, while simultaneously requiring higher levels of car use to increase council revenues obtained from parking fees. Lincolnshire County Council suggested there is a need to conduct a thorough audit of all on-street parking provisions within the city to examine whether the pricing structure, time restriction, and road markings (traffic regulation orders) are still as applicable for current parking and traffic needs as when originally installed. The officer thought that by improving these factors around parking operations, on-street parking regulations would be easier for drivers to understand and could reduce the likelihood of parking search.

\section{Discussion and conclusions}

The literature highlights that research on parking search has typically been undertaken from the perspective of drivers, while the perspectives of policymakers have not been equally well documented. This paper goes a little way toward addressing this imbalance by examining parking search through the perception of local government authority council officers.

Utilizing a qualitative semi-structured interview method removed the constraints that may have existed in an empirically based investigation and enabled wider issues around parking search to be explored with the respondents. This elicited thoughtful responses established from the interviewees' many years of experience working in the area of local authority parking and transport policy. The city, county, and borough council officers identified several areas concerning the main transport issues affecting cities in the United Kingdom, including the importance of considering parking management measures as an element of overall traffic policy. There was consensus that while parking search has the potential to have a serious negative impact on the smooth operation of the transport network and efficient traffic flow, as evident from the literature on parking search, and which the respondents fully recognized, all of the councils raised the issue that a lack of recorded evidence regarding the volume of vehicles searching for parking created difficulty in establishing existence of parking search and in quantifying the level of the problem. The council officers were aware of technological advances described in the literature, such as smartphone applications linked to sensors in parking bays, that could offer a solution to parking search, but thought the high implementation costs would be prohibitive unless parking search could be seen as having a greater impact on future traffic networks than currently existed in and around the main cities. For them, the immediate solution was seen to focus around the pricing and duration of parking, and the effective operation, quality, and signage of off- 
street parking provision working alongside on-street supply.

After further consideration regarding the current level of parking search occurring in each particular county, council officers concurred with the literature that spatial patterns of parking search existed, and each local authority agreed that on-street parking search was more likely to occur within peripheral urban areas away from city center cores. This was due to a lack of parking facilities of the type that are typically provided in central urban areas, such as large off-street surface car parks or multi-story parking facilities. Furthermore, parking search appeared to be more prevalent in larger market towns, which attract a large number of visitors for shopping and personal business purposes, but are not able to provide sufficient parking supply to meet peak period demand. In agreement with much of the literature, council officers identified significant temporal variations in parking search occurrences, typically arising from different trip purposes. For instance, the observation of increased parking search during evening times in several of the cities resulted from visitors; meanwhile, Saturdays experienced higher levels of parking search among shoppers during the late morning and early afternoon period, a pattern which was not evident among other trip purposes such as commuters. In common with much of the literature, council officers identified several individual characteristics, such as familiarity with an area or willingness to pay a level of parking fee that influenced an individual's parking search decision.

Despite the limited sample of 10 interviews with local government council officers in the East Midlands region of the United Kingdom, the interviews were considered to be agenda forming in terms of raising important issues around parking search, in particularly, increasing understanding of potential triggers and identifying potential future patterns of urban parking search. Currently, none of the local authorities had considered parking search as a serious problem that might require significant resources to address, since they had not observed it as being an issue in the cities in which they had responsibility for policy implementation. After considering the issue, the council officers agreed that parking search would most likely become a greater issue in the future as the UK economy recovers, population continues to expand, and car ownership and usage increase. The officers clearly viewed the potential for increasing parking search to disrupt traffic flow, giving rise to economic impacts through time delays, and were now beginning to evaluate the implementation of appropriate policy measures to address this.

Future research would comprise a wider UK study of parking search with council officers in other local government authorities, in particular to investigate metropolitan areas such as central London and large urban conurbations. Of importance in future research would be to enhance the qualitative methodology applied in this study with the collection of quantitative parking search data within UK cities to provide evidence that would challenge or support the subjective views of officers expressed in the interviews. Indeed, respondents stated that having quantitative evidence of parking search is extremely important, since a quantifiable evidence-base would enable local authorities to prioritize the development of policies to address parking search and defend against public scrutiny the associated allocation of resources. Having collected data, local authorities would be able to precisely identify which city areas, times of day, and days of the week parking search is more prevalent, thereby enabling targeted resource allocation. Given the technological developments that may in the future have a considerable influence on parking search (for instance, parking bay sensors and smartphone applications that enable advance detection of vacant parking spaces), a further important area of research would be to investigate the role of technology as it develops. This would include a thorough cost-benefit analysis, which local councils stated is vital to justify policy prioritization and budget allocation to parking measures over and above other budgetary considerations.

This paper has provided an alternative, qualitative approach to the understanding of parking search, based on the perspectives of transport and parking policymakers. This provides a contrast to much of the quantitative research that has investigated parking search from the viewpoint of drivers who are en- 
gaged in parking search activity and is important in terms of considering potential policy implications to reduce the occurrence of parking search in urban areas.

\section{References}

Anderson, S. P., and A. De Palma. 2004. The economics of pricing parking. Journal of Urban Economics 55(1): $1-20$.

Arnott, R., and E. Inci. 2006. An integrated model of downtown parking and traffic congestion. Journal of Urban Economics 60(3): 418-442.

Arnott, R., and E. Inci. 2010. The stability of downtown parking and traffic congestion. Journal of Urban Economics 68(3): 260-276.

Arnott, R., and J. Rowse. 2009. Downtown parking in auto-city. Regional Science and Urban Economics 39(1): $1-14$.

Axhausen, K. W., and J. W. Polak. 1989. The Role of Parking-Search Strategies in Understanding Parking Behavior. Oxford, UK: Transport Studies Unit, Oxford University.

Barter, P. A. 2012. Off-street parking policy surprises in Asian cities. Cities 29(1): 23-31.

Bryman, A. 2012. Social Research Methods, 4th edition. Oxford, UK: Oxford University Press.

Butler, E. 2012. Public Choice-A Primer. London: The Institute of Economic Affairs.

Caplan, B. 2002. Systematically biased beliefs about economics: Robust evidence of judgmental anomalies from the survey of Americans and economists on the economy. The Economic Journal 112(4): 433-458.

Chatman, D. G., and M. Manville. 2014. Theory versus implementation in congestion-priced parking: An evaluation of SFpark, 2011-2012. Research in Transportation Economics 44(6): 52-60.

Joffe, H., and L. Yardley. 2004. Content and thematic analysis. In Research Methods for Clinical and Health Psychology, edited by D. D. Marks and L. Yardley. London: SAGE Publications.

Manville, M. 2014. Parking pricing. In Parking: Issues and Policies, Transport and Sustainability (Vol. 5), edited by S. Ison and C. Mulley. Bingley, UK: Emerald Group Publishing Limited.

Marshall, W. E. 2014. On-street parking. In Parking: Issues and Policies, Transport and Sustainability (Vol. 5), edited by S. Ison and C. Mulley. Bingley, UK: Emerald Group Publishing Limited.

Millard-Ball, A., R. R. Weinberger, and R. C. Hampshire. 2014. Is the curb $80 \%$ full or $20 \%$ empty? Assessing the impacts of San Francisco's parking pricing experiment. Transportation Research Part A 63: 76-92.

Nawaz, S., C. Efstratiou, and C. Mascolo. 2013. ParkSense: A smartphone based sensing system for onstreet parking. MobiCom 2013, September 30-October 4, Miami.

Neuendorf, K. A. 2002. The Content Analysis Guidebook. Thousand Oaks, CA: SAGE Publications.

Pierce, G., and D. Shoup. 2013. Getting the prices right. Journal of the American Planning Association 79(1): 67-81.

Rye, T., and T. Koglin. 2014. Parking management. In Parking: Issues and Policies, Transport and Sustainability (Vol. 5), edited by S. Ison and C. Mulley. Bingley, UK: Emerald Group Publishing Limited.

Shoup, D. C. 2004. The ideal source of local public revenue. Regional Science and Urban Economics 34(6): 753-784.

Shoup, D. C. 2006. Cruising for parking. Transport Policy 13(6): 479-486.

Taylor, B., P. Haas, B. Boyd, D. Baldwin Hess, H. Iseki, and A. Yoh. 2002. Increasing Transit Ridership: Lessons from the Most Successful Transit Systems in the 1990s. San Jose, CA: The Mineta Transportation Institute, San Jose State University.

Van Ommeren, J. N., D. Wentink, and J. Dekkers. 2011. The real price of parking policy. Journal of Urban Economics 70(1): 25-31. 
Van Ommeren, J. N., D. Wentink, and P. Rietveld. 2012. Empirical evidence on cruising for parking. Transportation Research Part A: Policy and Practice 46(1): 123-130.

Weinberger, R. R. 2014. Three faces of parking: Emerging trends in the US. In Parking: Issues and Policies, Transport and Sustainability (Vol. 5), edited by S. Ison and C. Mulley. Bingley, UK: Emerald Group Publishing Limited. 